\title{
Is the inverse leafing phenology of the dry forest understory shrub Jacquinia nervosa (Theophrastaceae) a strategy to escape herbivory?
}

\author{
Óscar M. Chaves ${ }^{1} \&$ Gerardo Avalos ${ }^{1,2}$ \\ 1 Escuela de Biología, Universidad de Costa Rica, 2060 San José, Costa Rica; ochaves@costarricense.cr \\ 2 The School for Field Studies, Center for Sustainable Development Studies, 10 Federal St., Salem, MA 01970 USA; \\ avalos@fieldstudies.org
}

Received 03-VIII-2005. C Corrected 25-I-2006. Accepted 23-V-2006.

\begin{abstract}
In the dry forest of Santa Rosa National Park, Costa Rica, the understory shrub Jacquinia nervosa presents an inverse pattern of phenology that concentrates vegetative growth and reproduction during the dry season. In this study, we tested the "escape from herbivory" hypothesis as a potential explanation for the inverse phenological pattern of $J$. nervosa. We monitored leaf, flower and fruit production in 36 adult plants from October 2000 to August 2001. Leaves of six randomly selected branches per plant were marked and monitored every two weeks to measure the cumulative loss in leaf area. To analyze pre-dispersal seed predation we collected 15 fruits per plant and counted the total number of healthy and damaged seeds, as well as the number and type of seed predators found within the fruits. Leaf, flower, and fruit production occurred during the first part of the dry season (end of November to February). The cumulative herbivory levels were similar to those observed in other tropical dry forest tree species that concentrate leaf production during the wet season, and were concentrated on young leaves, which lost an average of $36.77 \%$ of their area $(\mathrm{SD}=34.35 \%, \mathrm{~N}=195)$. Chewing beetles of the genus Epicauta (Meloidae) were the most important herbivores. In mature leaves, most of the damage was caused by the beetle Coptocycla rufonotata (Chrysomelidae). Fruits took 4 months to develop during the dry season (January-March 2001) but continue increasing in size well into the first 3 months of the wet season (May-July). Average seed number per ripe fruit was $9(\mathrm{SD}=5, \mathrm{~N}=500)$. Seed predation in mature fruits was $42 \%(\mathrm{SD}=47 \%, \mathrm{~N}=122)$. Most seeds were damaged by moth larvae of the family Tortricidae. Only $3 \%$ of the flowers became fruits. This was influenced by the low level of flower synchrony $(0.38 \pm 0.26, \mathrm{~N}=36$ plants $)$, but neither leaf synchrony $(0.88 \pm 0.06, \mathrm{~N}=36$ plants $)$ nor plant size influenced fruit numbers. The significant damaged produced by insect herbivores in young leaves, fruits, and seeds, as well as the low reproductive index observed in $J$. nervosa, shows that the inverse leafing phenology of this species is not consistent with the "escape hypothesis" since $J$. nervosa was considerably attacked during the dry season. Considering the strong seasonality of the tropical dry forest and the heliophyte character of J. nervosa, it is more likely that this phenological strategy evolved in response to seasonal fluctuations in light availability, light quality, and daylength. Rev. Biol. Trop. 54 (3): 951-963. Epub 2006 Sept. 29.
\end{abstract}

Key words: escape hypothesis, Jacquinia nervosa, inverse phenology, insect herbivory, tropical dry forest.

Insect herbivores significantly influence plant fitness across ecological and evolutionary scales (Marquis 1984, Aide 1988, Cunningham 1997, Strauss and Armbruster 1997, Maron 1998). In tropical forests, leaf damage by herbivores can reach up to $7-20 \%$ of total leaf area (Edwards 1977, Dirzo 1984, Coley 1990, Coley and Barone 1996) although there is considerable variation in levels of damage (Braker and Chazdon 1993, Dirzo and Domínguez 1995). Even under moderate damage, herbivory, combined with other stress factors such as competition or water shortages, imposes important limits on plant survival and reproduction (Brown et al. 1987). For instance, moderate levels of leaf herbivory retarded vegetative growth and flowering in the understory shrub Piper arieianum (Marquis 1988), and 
damaged individuals of Gutierrezia sarothrae produced up to five times less seeds per branch relative to control plants (Wisdom et al. 1989). However, under certain circumstances, herbivory may have positive effects. Morrison and Reekie (1995) observed increased photosynthetic rates of undamaged leaves that compensated for the leaf area removed in Oenothera biennis. In addition, leaf herbivory could weed out the less resistant individuals in a population (i.e., Maschinski and Whitham 1989).

The wide diversity of evolutionary interactions between plants and their herbivores has favored the development of an extensive variety of chemical, mechanical, and phenological defenses (Coley and Barone 1996). In seasonal forests, plants that concentrate leaf, flower and fruit production during the dry season suffer less damage than species that grow and reproduce only during the wet season (Aide 1988, Coley and Barone 1996). During the dry season, insect abundance decreases relative to levels prevalent during the wet season (Wolda 1988). The idea that production of vegetative and reproductive modules during the dry season allows plants to escape in time from herbivores constitutes the "escape hypothesis"(Janzen 1970a, 1981). Following this hypothesis, a rapid and synchronic leaf, flower and fruit production facilitates most of the modules to survive the action of herbivores, which is usually concentrated on young leaves (Janzen 1970a, 1971, Coley and Barone 1996). In addition, highly synchronic flower production attracts a wide array of pollinators potentially increasing plant reproductive output (Gentry 1974, Augspurger 1981, 1983, Newstrom et al. 1994).

The expression of a phenological strategy is the outcome of the interaction among ecological (i.e., water availability, and quality and quantity of light) and evolutionary factors (i.e., impact of herbivores, pathogens, and competitors). In tropical dry forests, water stress and decreased water supply have been considered the primary conditions leading to leaf shedding (Borchert 1983, 1999, Justiniano and Fredericksen 2000, Borchert et al. 2002, Brodribb and Holbrook 2003), although light quality and photoperiod may also serve to synchronize leaf flushing and leaf shedding (Rivera et al. 2002). Species lose and maintain leaves depending on their capacity to resist water stress according to gradients of water availability in the soil and their biomass allocation to roots (Borchert 1994, Jackson et al. 1995). In contrast to the majority of tree species that shed leaves at the onset of the dry season and remain leafless until the onset of the rains, a few species present the inverse leaf phenological pattern, in which leaves are produced during the dry season and shed during the wet season (Janzen 1970b, Roupsard et al. 1999). At Santa Rosa National Park, Costa Rica, the only species with this type of leafing phenology is the understory shrub Jacquinia nervosa (Janzen 1970b, Daubenmire 1972, Wright 1996). The expression of an inverse leafing phenology could be influenced by evolutionary factors, such as plant-herbivore interactions. Following the "escape hypothesis" the pressure exerted by insect herbivores concentrates leaf production during the season of lowest insect abundance (Janzen 1967, 1971, Wright 1996).

This study examines how effective the "escape hypothesis" is to explain the phenological behavior of $J$. nervosa. If this hypothesis has the potential to apply to this case, we would expect low levels of leaf, fruit and seed herbivory relative to reported values for other deciduous species within the same habitat. To answer this question we determined: (a) the percentage of herbivory in leaves and seeds in comparison to other dry forest species that grow and reproduce during the wet season; (b) the effect of the magnitude of leaf flushing synchrony and plant size on reproductive success; and (c) the type of herbivores associated to leaves, fruits, and seeds. Studying the influence of herbivores on the timing of leaf flushing will help to understand the role of proximate and ultimate factors on the expression of the inverse leafing phenology in this dry forest understory shrub. 


\section{MATERIALS AND METHODS}

Study site: This study was carried-out for 12 months (May-July 2000, and November 2000 to August 2001) in the "Indio Pelado" trail in Santa Rosa National Park, Guanacaste, Costa Rica. Santa Rosa is located between the Gulf of Papagayo and the Interamerican Highway $\left(10^{\circ} 44^{\prime} 13^{\prime \prime}-11^{\circ} 00^{\prime} 37^{\prime \prime} \mathrm{N}\right.$, and $\left.85^{\circ} 34^{\prime} 48^{\prime \prime}-85^{\circ} 58^{\prime} 51^{\prime \prime} \mathrm{W}\right)$ at $290 \mathrm{~m}$ in elevation. The upper plateau maintains tropical premontane forests, whereas the coastal lowlands present a large extension of Tropical Dry Forests (Tosi 1969). Average annual rainfall is $1423 \mathrm{~mm}$, being September and October the wettest months. Average annual temperature is $25.7^{\circ} \mathrm{C}$, and relative humidity is $81 \%$ (Santa Rosa National Park Climatic Records). The dry season extends from late November through April. During the dry season, nearly $70 \%$ of the canopy trees are deciduous (Hartshorn 1983). The "Indio Pelado" trail is dominated by secondary forests composed primarily of seedlings and saplings of canopy species and understory shrubs (i.e., Cochlospermum vitifolium, Semialarium mexicanum, J. nervosa), trees of 10-20 m in height (i.e., Spondias mombin, Bursera simaruba), and a few 20-35 m old trees remaining from the original forests (i.e., Pachira quinata, Manilkara chicle, Hymenaea courbaril and Pseudobombax septenatum).

Study system: J.nervosa(Theophrastaceae) is an understory shrub abundant in deciduous and semideciduous forests of the Pacific coast of Central America. It ranges from southern Jalisco, Mexico, to northeastern Costa Rica (Ståhl 1989) where a density of 0.1 to 60 adults per ha has been registered (Janzen 1970b). Adults vary 1.5-6 m in height with a diameter at breast height (DBH) of $1.5-20 \mathrm{~cm}$.

This shrub, like the rest of the 33 species in the genus Jacquinia, has coriaceous, simple and alternate leaves, and a modified leaf apex in the shape of a spine (Ståhl 1995). The root system is very deep with little ramifications close to the soil surface (Janzen 1970b, 1983, Oberbauer 1985). A characteristic that distinguishes it from other Theophrastaceae, and from most tree and shrub species in the dry forest, is an inverse leaf phenological pattern: $J$. nervosa flushes new leaves at the beginning of the dry season, and becomes deciduous at the start of the rainy season (Janzen 1970b, 1983).

Fruit production takes place two months after flower production. Immature fruits are dull green with an orange juicy pulp and dark brown seeds. When seeds mature the seminal cover turns orange, increases in thickness, and becomes stony. After dehydrating, seeds and pulp become sweet. The actual pollinators and seed dispersers are not known. Janzen (1970b) suggests that hummingbirds are possible pollinators, but he did not specify a particular species. Gillespie (1999) suggests that it is mammal-dispersed.

Monitoring of plant phenology: We randomly selected 36 adults (ranging 1.4-5 $\mathrm{m}$ in height), and in each individual we marked 20 external branches whose position at the top or bottom of the crown was determined at random. We then measured leaf, flower, and fruit production on these individuals 1-3 times at month, from November 2000 to August 2001.

Measurement of leaf herbivory: To measure average leaf area lost to herbivores we randomly chose six branches per plant of the above-mentioned individuals, and marked every damaged leaf in all the branches. Leaf loss was quantified through censuses done every 15 days during the study period. To estimate leaf area we collected 200 leaves from different individuals, and measured their length and width. Leaf area was measured using a LI-Cor LI-3100 leaf area meter (Li-Cor Inc., Lincoln, Nebraska) calibrated in $\mathrm{cm}^{2}$. Using these results we calculated a linear regression to predict leaf area based on leaf length and width measurements non-destructively in the field $\left(\mathrm{r}^{2}=0.97, \mathrm{~F}=36.5, \mathrm{~N}=125, \mathrm{p}=0.001\right)$. In addition, we used a plastic transparency with a millimeter grid to quickly estimate the leaf area removed by insects. Based on this, we established seven categories of damage 
relative to the percentage of leaf area lost to herbivores: 0 (0\%), 1 (1-10\%), 2 (11-25\%), $3(26-35 \%), 4(36-50 \%), 5(51-75 \%)$ and 6 (76-99 \%) following Morrow (1984). In addition, we performed bi-weekly observations of the presence and identity of herbivores on eight external branches in each of $20 \mathrm{~J}$. nervosa mature plants. Observations were done early in the morning (6:00-8:00 am) and at night (17:30-19:30 pm). We registered and collected the type of herbivores present on the plant with an aspirator and an entomological net. We identified herbivores to species, genus, or family and classify them according with the most important damage they inflicted on the plant (Table 1).

Assessment of fruit and seed herbivory: Every 15 days (from March to August 2001) we collected 10-20 fruits per plant, measured fruit diameter, and crack fruits open and inspected them for healthy and damaged seeds, as well as the number and type of insects found inside the fruits. Fruits containing larvae were placed inside plastic bags to facilitate the emergence of the adults for later identification.

\section{Measurement of phenological sinchro-} ny and reproductive success: We estimated synchrony in leaf, flower and fruit production following Augspurger (1983): $X_{i}=\sum e_{j=i} /(n-1) f_{i}$ where $e_{i}$ represents the days when individuals $i$ and $j$ produced leaves synchronically, $f_{i \text { represents }}$ leaf life span in individual $i, n$ represents sample size, and $X_{i}$ represents the magnitude of population synchrony. This index ranges from 0 (total asynchrony) to 1 (100\% synchrony in the population). Individual reproductive success $\left(\mathrm{E}_{\mathrm{i}}\right)$ was determined following Fuchs (2000): $\mathrm{E}_{\mathrm{i}}=\left(\mathrm{f}_{1} / \mathrm{f}_{2}\right) * 100$, where $f_{1}$ is the number of mature fruits and $f_{2}$ is the total number of flowers per plant. Reproductive success at the population level corresponds to the average value of the $E_{i}$ across all individuals.

TABLE 1

List of insect herbivores found in $\mathrm{J}$. nervosa

\begin{tabular}{|c|c|c|c|c|c|}
\hline Group & $\begin{array}{l}\text { Number } \\
\text { of species }\end{array}$ & Stage $^{1}$ & Diet $^{2}$ & Damage category & Damage level ${ }^{3}$ \\
\hline Acari & 1 & $\mathrm{a}, \mathrm{j}$ & $\mathrm{ml}$ & sucker & U.D. \\
\hline Afidae & 2 & $a, j$ & $\mathrm{j} 1$ & sucker & U.D. \\
\hline Coptocycla & 2 & $\mathrm{a}$ & $\mathrm{ml}$ & scraper & 3 \\
\hline Hemiptera & 1 & $\mathrm{a}$ & $\mathrm{ml}$ & sucker & 1 \\
\hline Cicadellidae & 4 & $\mathrm{a}, \mathrm{j}$ & $\mathrm{ml}$ & sucker & 2 \\
\hline Curculionidae & 2 & $\mathrm{a}, \mathrm{j}$ & $\mathrm{fr}$ & driller & 2 \\
\hline Hymenoptera & 1 & $\mathrm{j}$ & $\mathrm{jl}, \mathrm{ml}$ & miner & 1 \\
\hline Grillidae & 4 & a & $\mathrm{jl}, \mathrm{fl}$ & chewer & 2 \\
\hline Lepidoptera & 1 & $\mathrm{j}$ & $\mathrm{fr}, \mathrm{s}$ & chewer & 3 \\
\hline Epicauta & 1 & a & $\mathrm{j} 1$ & chewer & 4 \\
\hline Miridae & 1 & a & $\mathrm{ml}$ & sucker & 1 \\
\hline Pentatomidae & 3 & a & $\mathrm{ml}, \mathrm{fr}$ & sucker & 1 \\
\hline Tortrichidae & 1 & $\mathrm{j}$ & $\mathrm{fr}, \mathrm{s}$ & chewer & 5 \\
\hline \multicolumn{6}{|c|}{$\mathrm{a}=$ adult, $\mathrm{j}=$ juvenile } \\
\hline \multicolumn{6}{|c|}{$\mathrm{jl}=$ juvenile leaves, $\mathrm{ml}=$ mature leaves, $\mathrm{fr}=$ fruits, $\mathrm{fl}=$ flowers, $\mathrm{s}=$ seeds } \\
\hline \multicolumn{6}{|c|}{ U.D. $=$ undetermined, $1=$ light, $2=$ moderate, $3=$ moderate to high, $4=$ high, $5=$ very high. } \\
\hline
\end{tabular}


Flower visitors and pollinators: We collected a random sample of $30 \mathrm{~J}$. nervosa flowers from eight different plants to prepare a pollen reference collection. Throughout the study period, we recorded observations of the flower visitors of $J$. nervosa. Every 15 days, we sampled all flowers present in 20 marked branches of 22 reproductive plants of $J$. nervosa, and made observation in the morning (8:00-11:00 am) and at night (19:00-21:30 pm), and recorded every visitor to $J$. nervosa flowers. With an aspirator we collected all insect visitors that were examined for pollen loads to be compared with our reference collection afterwards. With a stereoscopy, we observed samples of the collected specimens and looking for pollen.

Statistical analyses: We compared herbivory levels among young and mature leaves using a t-test. A Kruskal-Wallis analysis was used to compare temporal changes in herbivore damage among mature leaves produced in different dates, as well as levels of seed predation by date. For comparing synchrony level between leaves, flowers, and fruits we used one factor ANOVA. A multifactorial ANOVA was used to determined how leaf and flower synchrony, as well as plant size, influenced the level of reproductive success with the following model: $\mathrm{Y}=\mu+x_{1}+x_{2}+x_{3}+\mathrm{e}$, where $\mathrm{Y}$ represents reproductive success, $x_{1}$ is leaf synchrony, $x_{2}$ is flower synchrony, $x_{3}$ is plant size, and e is the residual error. Data were logtransformed to correct for deviations from the normal distribution. All the analyses were done using SYSTAT 9.0 (SYSTAT 1999).

\section{RESULTS}

Phenology: Leaf, flower and fruit production took place in the first part of the dry season (end November to February). In most plants, leaf flushing occurred simultaneously with the production of flower buds, although the magnitude and temporal trajectories were different (Fig. 1A). Anthesis began in mid January and reached a peak in the first week of February, when the first fruits were also formed. The main fruiting peak occurred in mid February; there was also a slight increase in fruit numbers by the end of February (Fig. 1B). Only $12 \%$ of a total of 440 immature fruits developed into mature fruits by March (see peak in fruit production, Fig. 1C). Fruits had an average diameter of 1.80 $\mathrm{cm}(\mathrm{SD}=0.37, \mathrm{~N}=500)$, and an average of 9.11 seeds per fruit $(\mathrm{SD}=5.36, \mathrm{~N}=500)$.

Synchrony in leaf, flower, and fruit production: Average synchrony at the population level in leaf, flower and fruit production showed significant differences $\left(F_{1,32}=122.7\right.$, $\mathrm{p}<0.001)$. Leaf production was the most synchronic phonological trait $(0.88, \mathrm{SE}=0,012)$,

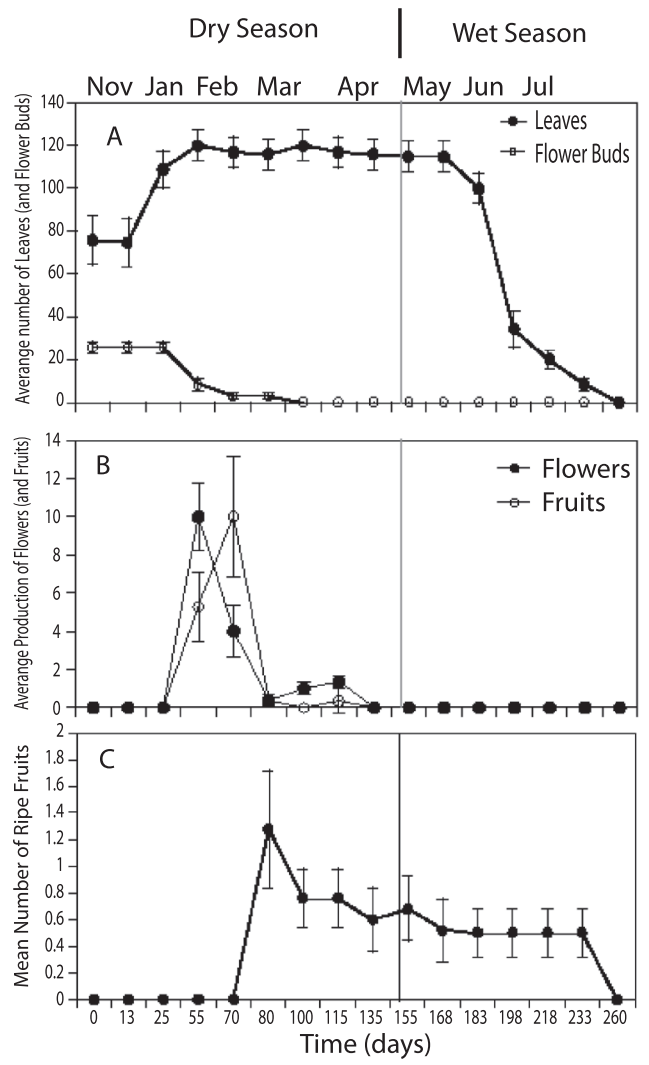

Fig. 1. A. Average number of leaves and flower buds ( \pm 1 S.E.); B. number of flowers and immature fruits; and C. ripe fruits in 36 adult individuals of $J$. nervosa, November through August 2001, Santa Rosa National Park, Costa Rica. 
whereas fruit production $(0.18, \mathrm{SD}=0.03)$ showed the lowest synchrony followed by flower production $(0.39, \mathrm{SD}=0.05)$.

\section{Remotion of leaf area by herbivores:} Significant differences were found in herbivory levels among young leaves produced at the start of the growing season (late Novemberearly December 2000) and mature leaves (ttest, $\mathrm{p}=0.04$ ). Young leaves lost an average of $36.77 \%$ of their area, with significant within plant variation. Herbivory levels of mature levels changed little throughout the growing season although they steadily increased over time (Kruskal-Wallis, $\mathrm{p}=0.11$; Fig. 2). Main herbivores of young leaves were chewing insects, especially the beetle Epicauta sp. (Meloidae). Although mature leaves presented different types of insect herbivores, the most important damage was caused by the scraper beetle Coptocycla rufonotata (Chrysomelidae), which removed the leaf mesophyll on both leaf surfaces leaving the vascular system exposed. In addition, $8.22 \%$ of the plants had damage caused by larvae of an unidentified hymenopteran leaf miner (Table 1).

Seed and fruit herbivory: Seed predation varied significantly over time (KruskalWallis, $\mathrm{p}<0.001)$. Although these values have high variation from plant to plant, it is clear

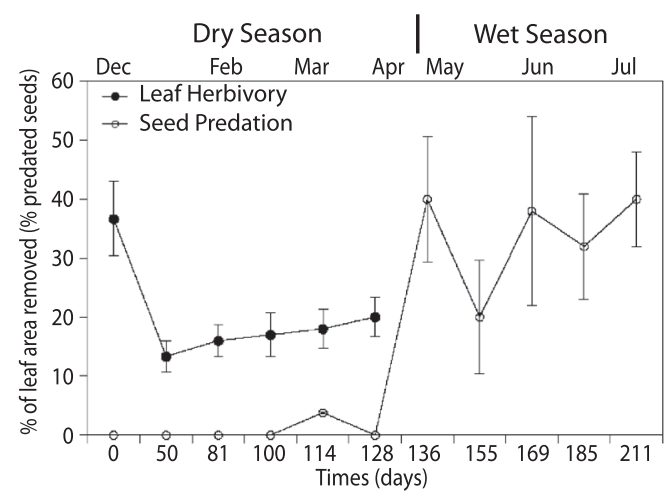

Fig. 2. Average percentage of herbivory damage ( $\pm 1 \mathrm{SE}$ ) caused by insect herbivores in mature leaves and fruits of 36 adult individuals of $J$. nervosa from December 2001 to July 2001, Santa Rosa National Park, Costa Rica. that predispersal seed predation increased over time as seeds accumulate more time being exposed to herbivores (Fig. 2). Average seed predation in the first fruits produced in March was $1.04 \%(\mathrm{SD}=5.43, \mathrm{~N}=85)$, whereas by July it increased to $42.3 \%(\mathrm{SD}=47.2 \%, \mathrm{~N}=$ 122). The number of viable seeds per fruit went from $10.46(\mathrm{SD}=4.04, \mathrm{~N}=115)$ at the end of March to $5.3(\mathrm{SD}=5.53, \mathrm{~N}=193)$ at the end of July. This represents a reduction of $50 \%$ in the number of viable seeds per fruit. Forty four percent out of 550 fruits (both ripe and unripe) were predated. Of the damaged fruits, moth larvae of the family Tortricidae were responsible for $27 \%$ of the damage, $7 \%$ was caused by an unidentified moth larvae, $4 \%$ by Curculionid larvae, and $6 \%$ were damaged by a combination of Tortricidae and Curculionid larvae considering the abundant excreta from these two found inside fruits in combination with Zygomicete fungi (Table 1). Similar fungi were also found in $16.4 \%$ of fruits with larvae inside. About $94.3 \%$ of the plants had a variable number of fruits that aborted very early. We cannot ascribe these levels of fruit abortion to the sole action of herbivores, since $J$. nervosa presents dichogamy and it could be that abortion is a consequence of self-incompatibility rather than herbivore damage alone.

Reproductive success: This parameter was low showing an average of $3.4 \%$, although variation among plants was high $(\mathrm{SD}=7.6, \mathrm{~N}=$ 36). Fruit production was considerably affected by flower synchrony $\left(\mathrm{F}_{3,14}=2.01, \mathrm{p}=0.027\right)$, but neither by the synchrony of leaf production $\left(\mathrm{F}_{1,3}=1.08, \mathrm{p}=0.32\right)$ nor by plant size $\left(\mathrm{F}_{1,2}=\right.$ $0.28, \mathrm{p}=0.76$ ).

Potential pollinators: During this study, we did not observe hummingbirds or any other potential vertebrate pollinator near $J$. nervosa flowers, neither bees landing on the flowers. In contrast, ants of the family Myrmicinae were observed on the plants throughout the entire flowering period, especially feeding on intrafloral nectaries. Thirty out of 40 individuals of this ant had pollen grains on their bodies. In addition, 
we observed trips (Thripsidae) on anthers in $93 \%$ out of 470 open flowers from different individuals. Again, $93 \%$ out of 60 trips had pollen on their bodies. In flowers of all plants, anthers get ripe before the stigma, being possible to find flowers of both types (functionally male and female flowers) in the same individual. Immediately after anthesis, the stamens join together enclosing the pistil, and separate 3-5 days later to leave the pistil exposed facilitating the arrival of pollen on the stigma.

\section{DISCUSSION}

Dry season phenology: The timing of leaf production in tropical plants is associated with favorable periods for growth and carbon fixation. In weakly seasonal forests leaf, flower and fruit production is concentrated in the driest time of the year to take advantage of peaks in light availability (Janzen 1967, Gentry 1974, Wright and Cornejo 1990, van Shaik et al. 1993). In the dry forest, the intensive and long dry season provokes water stress, high irradiation, high temperatures, and higher evapotranspiration, limiting vegetative growth, and triggering flower and fruit production. In J. nervosa, both leaf and flower production, as well as the bulk of the fructification period, were concentrated during the dry season, whereas plants become deciduous and remain dormant during the wet period. The same phenological pattern has been described for Faidherbia albida in the dry forests and savannas of West Africa (Wickens 1969, Roupsard et al. 1999). In this legume, the phreatophitic character facilitates survival during droughts, as well as leaf, flower and fruit production during this very stressful period. Leaves are dropped after the start of the rains possibly due to light reduction and canopy closure, analogous to $J$. nervosa (Chaves and Avalos, in prep.).

Levels of herbivory: During the dry season, high radiation, lack of water, and the scarcity of fresh foliage create adverse conditions for the growth and survival of insect herbivores (Janzen 1967,1971, Frith and Frith 1985, Wolda 1988, 1990, Smythe 1990). Consequently, plants that flush new leaves and reproduce during the dry season should have a head start relative to plants that flush leaves during the wet season, since they will experience lower herbivory damage (Aide 1988, 1992, Mopper and Simberloff 1995). Janzen $(1967,1971,1981)$ shows that plants with this behaviour escape in time from their herbivores. In J. nervosa, Janzen (1970b) observed low levels of herbivory in leaves, fruits and seeds (although these levels were not quantified), concluding that $J$. nervosa is immune to herbivores, parasites and diseases due to its leaf phenology and the defensive compounds of seedlings and adults. However, the levels of herbivory observed in our study in young leaves and fruits cast doubts on the generality of Janzen's findings.

In tropical dry forests, woody plants loose an average of $14.2 \%$ of leaf area per year to herbivores, whereas shade tolerant species in tropical rain forests loose $11.1 \%$ (Barone and Coley 2002). Janzen (1981) found that most plants presented small to moderate damage, and very few presented no damage or drastic damage, at Santa Rosa National Park during the rainy season. At Palo Verde National Park, Costa Rica, Dirzo and Domínguez (1995) measured the percentage of leaf area damaged by herbivores during the rainy season and found in a sample of 45 plants from 33 tree species (all deciduous) that $71 \%$ lost between 1-12\% their area, whereas $11 \%$ lost between 25-50\% of leaf area. In the dry forest of Chamela, Mexico, Filip et al. (1995) measured leaf area loss in 16 deciduous species between 1983 and 1985 , and found similar levels of damage along three consecutive years $(6.7 \%, 9.2 \%$, and $7.8 \%$ respectively). These percentages of leaf damage are below those of $J$. nervosa, although the differences could be methodological, since in the above-mentioned studies herbivory was measured as punctual observations and not as repeated measures over time on the same leaves, as in the present study. Punctual observations often subestimate herbivory (Morrow 
1984, Coley and Barone 1996), since they do not consider the damage accumulated over the leaf life span. This subestimation may range $38-60 \%$, and varies according to species (Lowman 1984, Filip et al. 1995). For instance, when comparing leaf area loss through punctual measurements versus repeated measures in 12 deciduous species in Chamela, Filip et al. (1995) found damage levels of $7.57 \%$ and $17.13 \%$, respectively; however, there was significant variation among species. Such damage levels are similar to the ones found in $J$. nervosa in this study. Restricting leaf production to the dry season does not allow $J$. nervosa to reduce herbivore damage, since damage levels are similar (or higher in many cases) to those reported for plants that produce leaves during the rainy season.

The high levels of herbivory found in young leaves of $J$. nervosa relative to mature leaves have been observed in tropical forests, as well as in temperate forests (Morrow 1984, Marquis and Braker 1994, Coley and Kursar 1996). In tropical rain forests, young, expanding leaves experience a daily rate of damage 2-24 times higher than that of mature leaves (Coley and Barone 1996). Young leaves are less lignified, have a lower amount of fibers, a greater concentration of nitrogen, and in many cases, an incipient "arsenal" of secondary metabolites as compared to mature leaves (Lieberman and Lieberman 1984, Bazzaz et al. 1987, Coley 1990). According to Coley and Barone (1996), even when young leaves are better protected than mature leaves, the defenses are not sufficient to counteract their attractive characteristics. Therefore, in most plants herbivores prefer younger leaves.

Insect herbivores pose an important selective pressure on rapid leaf expansion, which in turn reduces the period of exposure to herbivory. In $J$. nervosa leaf expansion took 3-4 weeks. This period was not sufficient to "escape" from the more voracious herbivores such as the meloid beetle Epicauta sp., which were abundant at the start of the dry season. Mature leaves did not escape either from damage caused by the scraper beetle Coptocycla rufonotata. In addition, the high fruit and pre-dispersal seed predation is not consistent with the "escape" hypothesis. In contrast to Janzen (1970b) a high proportion of fruits and seeds in Jacquinia did not escape damage by moth larvae of the Family Tortricidae and curculionid beetles.

In Tropical Dry Forests insects are the most important seed predators (Janzen 1987). In Santa Rosa, Janzen $(1980,1981)$ found that 100 plant species out of 975 had regularly beetle larvae inside seeds. In Samanea saman $43 \%$ of 14.419 seeds were destroyed by the weevil Merobruchus columbinus (Janzen 1977a). The damaged caused by frugivorous insects in $J$. nervosa falls within the range reported in these studies, although such damage could be underestimated since we did not take into account the number of aborted seeds and fruits, which could be the consequence of the combined action of insect predation (Janzen 1977b, Leopold and Kriedemann 1975, Stephenson 1981) and self-incompatibility.

Frugivorous insects must cope with plant secondary compounds and vertebrate frugivores. Larvae complete their development and emerge from the fruits before these become attractive for dispersal agents (Sallabanks and Courtney 1992, Greig 1993, Restrepo 2002). These insects could also make the fruit distasteful for vertebrates due to the bacterial and fungal colonization exudates within cavities dug out by insect larvae (Janzen 1977b, Stiles 1980, Herrera 1989). This could explain the presence of fungi and insect droppings inside $J$. nervosa fruits. The fact that fruit retention in this species is delayed two consecutive dry seasons shows the scarcity of efficient dispersers (Janzen 1970b), and indicates that vertebrate dispersers are not an important selective pressure for frugivorous insects. This facilitates the development of butterfly and curculionid larvae inside $J$. nervosa fruits, thus reducing the number of viable seeds. For this reason, the percentage of damaged seeds at the start of the wet season of 2000 was $97 \%$.

Potential pollinators: Janzen (1970b) suggests that hummingbirds could be the potential 
pollinators of $J$. nervosa, although he did not mention any species in particular and saw only two visits to flowers. We did not observe any vertebrate visiting the flowers. Knudsen and Ståhl (1994) suggest that $J$. nervosa is very likely pollinated by bees, as deduced from flower morphology and scent chemistry. However, only in very rare occasions we observed bees visiting flowers of $J$. nervosa. We observed different types of ants and trips visiting flowers and carrying pollen, but their actual role as pollinator has not been established. In tropical dry forest trees conspicuous flowers pollinated by specialized insects predominate (Janzen 1967, Frankie 1975). About two thirds to $75 \%$ of wood plants are associated with specialized pollinators, such as medium sized bees, hummingbirds and butterflies; the rest have generalist pollinators, or are wind pollinated (Gentry 1995). Generalist systems of pollination are favored in cases when specialized pollinators are rare (Richards 1997), such at the start and at the end of the dry season. This is congruent with the flowering pattern shown by J. nervosa. In addition, the temporal isolation provoked by the differential development of reproductive structures in $J$. nervosa may represent a mechanism that avoids self-pollination and promotes pollen flow (Richards 1997). Selfincompatibility is a widespread phenomenon in tropical dry forest, where $79.4 \%$ of the trees at La Pacifica, Guanacaste, are self-incompatible (Bawa 1974). This also helps to explain the low fruit production observed in this study.

Synchrony and reproductive success: Synchronic leaf and flower production is a frequent phenomenon in tropical plants (Augspurger 1981,1983, House 1992, Wheelwright 2000), and is especially intense in seasonally dry forests (Janzen 1967, Frankie et al. 1974, Fuchs 2000). Species with high leaf synchrony present considerably less damage by herbivores relative to species with low leaf synchrony (Coley 1980, Lieberman and Lieberman 1984, Aide 1988, 1992, Coley and Barone 1996). However, despite the high synchrony in leaf production observed in $J$. nervosa, young leaves suffered high levels of herbivory. In contrast, flower and fruit synchrony was highly variable among plants. This high variability could be the result of environmental heterogeneity, genetic variation, phenotypic plasticity, or a combination of these factors (Rathcke and Lacey 1985). Flower production could be induced by environmental signals such as changes in the quality of light and variable soil humidity, factors that could synchronize the expression of these phenological characters within a population (Leopold and Kriedemann 1975, Augspurger 1983, 1990, Borchert 1983, 1995). If the distribution of environmental signals is not homogenous within a population, the synchronization is low (Augspurger 1983, 1990, Newstrom et al. 1994). In the majority of tropical dry forest plants the signal that induces phenological synchronization is the rain (Borchert 1983, 1999, Augspurger 1990, Murphy and Lugo 1995). Recent evidence indicates that light quality, as determined by changes in daylength, also has a determinant role (Borchert et al. 2005). However, for $J$. nervosa changes in levels of canopy openness and access to radiation could play a much more important role in flower and fruit production (Janzen 1970b, Chaves and Avalos in prep).

The low reproductive success of $J$. nervosa is similar to those observed in other deciduous species at the study site. For instance, Fuchs (2000) determined that in different fragmented populations of the bombacaceous tree Paquira quinata the number of flowers that developed into mature fruits ranged $0.85-4.97 \%$ out of the total number of produced flowers. The low fruit output characteristic of many species could the consequence of lack of efficient pollinators (Newstrom et al. 1994, Johnson and Steiner 2000, Murcia 2002), fruit abortion induced by herbivores, self-incompatibility, or a combination of all these factors. If there is self-incompatibility (as it seems to be the case in $J$. nervosa) this could result in a selective abortion of seeds and immature fruits (Leopold and Kriedemann 1975, Richards 1997).

In summary, the "escape" hypothesis is not congruent with the phenological pattern of $J$. 
nervosa. This dry forest understory shrub was affected by a diverse assemblage of leaf herbivores active during the dry season. Considering the strong seasonality of tropical dry forests, and the heliophyte character of $J$. nervosa, it is more likely that abiotic factors, such as seasonal changes in light availability, light quality and photoperiod could have worked more effectively as selective factors in the evolution of the inverse leafing phenology.

\section{ACKNOWLEDGMENTS}

We thank Oscar Rocha for his input during fieldwork and on the manuscript, as well as for his logistical support. María Marta Chavarría and Felipe Chavarría provided valuable help during fieldwork. Álvaro Segura and Sandra Pérez helped identifying frugivore insects. The Organization for Tropical Studies, through an Andrew W. Mellon Scholarship, and the Organization Idea Wild provided logistical and financial support.

\section{RESUMEN}

Analizamos la hipótesis de "escape de la herbivoría" como explicación para la fenología foliar inversa del arbusto de sotobosque del bosque seco Jacquinia nervosa, el cual produce sus hojas durante la estación seca y se mantiene sin ellas durante la estación lluviosa. Medimos la producción de hojas, flores y frutos, el daño por herbivoría en hojas y semillas, y la fauna de herbívoros en 36 plantas adultas de octubre del 2000 a agosto del 2001 en Santa Rosa, Costa Rica. La herbivoría foliar acumulada durante la estación seca fue similar a la herbivoría de otras especies que concentran la producción foliar en la estación lluviosa. En las hojas maduras la mayor parte del daño fue causado por el escarabajo Coptocycla rufonotata (Chrysomelidae). La depredación de semillas predispersión fue de $42 \%$ $(\mathrm{DE}=47 \%, \mathrm{~N}=122)$ y es causada por larvas de polilla de la familia Tortricidae. Los niveles de daño indican que la fenología foliar de $J$. nervosa no coincide con la hipótesis de "escape". Considerando la fuerte estacionalidad del bosque seco y el carácter heliófito de $J$. nervosa, es probable que esta estrategia fenológica evolucionara en respuesta a cambios estacionales en la disponibilidad y calidad de la luz, y duración del fotoperíodo.
Key words: escape hypothesis, Jacquinia nervosa, inverse phenology, insect herbivory, tropical dry forest.

\section{REFERENCES}

Aide, T.M. 1988. Herbivory as a selective agent on the timing of leaf production in a tropical understory community. Nature 336: 574-575.

Aide, T.M. 1992. Dry season leaf production: an escape from herbivory. Biotropica 24: 532-537.

Augspurger, C.K. 1981. Reproductive synchrony of a tropical shrub: experimental studies on effects of pollinators and seed predators on Hybanthus prunifolius (Violaceae). Ecology 62: 775-778.

Augspurger, C.K. 1983. Phenology, flowering synchrony, and fruit set of six neotropical shrubs. Biotropica 15: 257-267.

Augspurger, C.K. 1990. Una señal para la floración sincrónica, p. 201-218. In E.G. Leigh Jr., A.S. Rand \& D.M. Windsor (eds.). Ecología de un Bosque Tropical: ciclos estacionales y cambios a largo plazo. Instituto Smithsonian de Investigaciones Tropicales, Panamá, Panamá.

Barone, J.A. \& P.D. Coley. 2002. Herbivorismo y las defensas de las plantas, p. 464-492. In M.R. Guariguata \& G.H. Kattan (eds.). Ecología y conservación de bosques neotropicales. LUR, San José, Costa Rica.

Bawa, K.S. 1974. Breeding systems of tree species of a lowland tropical community. Evolution 28: 85-92.

Bazzaz, F.A., N.R. Chiariello, P.D. Coley \& L.F. Pitelka. 1987. Allocating resources to reproduction and defense. Bioscience 37: 58-66.

Bloem, K.A., K.C. Kelley \& S.S. Duffey. 1989. Differential effect of tomatine and its alleviation by cholesterol on larval growth and efficiency of food utilization in Heliothis zea and Spodoptera exigua. J. Chem. Ecol. 15: 387-398.

Borchert, R. 1983. Phenology and control of flowering in tropical trees. Biotropica 15: 81-89.

Borchert, R. 1994. Soil and stem water storage determine phenology and distribution of tropical dry forest trees. Ecology 75: 1437-1449.

Borchert, R. 1995. Phenology and flowering periodicity of neotropical dry forest species: evidence from herbarium collections. J. Trop. Ecol. 12: 65-80. 
Borchert, R. 1999. Climatic periodicity, phenology, and cambium activity in tropical dry forest trees. IAWA J. 20: 239-247.

Borchert, R., G. Rivera \& W. Hagnauer. 2002. Modification of vegetative phenology in a Tropical Semi-deciduous Forest by abnormal drought and rain. Biotropica 34: 27-39.

Borchert, R., S.S. Renner, Z. Calle, D. Navarrete, A. Tye, L. Gautier, R. Spichiger \& P. von Hildebrand. 2005. Photoperiodic induction of synchronous flowering near the Equator. Nature 433: 627-629.

Braker, E. \& R.L. Chazdon. 1993. Ecological, behavioural, and nutritional factors influencing use of palms as host plants by a Neotropical forest grasshopper. J. Trop. Ecol. 9: 181-195.

Brodribb, T.J. \& N.M. Holbrook. 2003. Stomatal closure during leaf dehydration, correlation with other leaf physiological traits. Plant Physiol.132: 2166-2173.

Brown, V.K., A.C. Gange, I.M. Evans \& A.L. Storr. 1987. The effect of insect herbivory on the grown and reproduction of two annual Vicia species at different stages in plant succession. J. Ecol. 75: 1173-1189.

Coley, P.D. 1980. Effects of leaf age and plant life-history on herbivory. Nature 284: 545-46.

Coley, P.D. 1990. Tasas de herbivorismo en diferentes árboles tropicales, p. 191-200. In E.G. Leigh Jr., A.S. Rand \& D.M. Windsor (eds.). Ecología de un Bosque Tropical: ciclos estacionales y cambios a largo plazo. Instituto Smithsonian de Investigaciones Tropicales, Panama, Panama.

Coley, P.D. \& J.A. Barone. 1996. Herbivory and plant defenses in tropical forest. Ann. Rev. Ecol. Syst. 27: 305-335.

Coley, P.D., \& T.A. Kursar. 1996. Anti-herbivore defenses of young tropical leaves: physiological constraints and ecological tradeoffs, p. 305-336. In S.S. Mulkey, R.L. Chazdon \& A.P. Smith (eds.). Tropical Forest Plant Ecophysiology. Chapman \& Hall, New York, New York, USA.

Cunningham, S.A. 1997. Predator control of seed production by a rain forest understory palm. Oikos 79: 282-290.

Daubenmire, R. 1972. Phenology and other characteristics of the tropical semideciduous forest in Northwestern Costa Rica. J. Ecol. 60: 147-170.

Dirzo, R. 1984. Insect-plant interactions: some ecophysiological consequences of herbivory, p. 209-224. In E. Medina, H.A. Money \& C. Vázquez-Yánes (eds.).
Physiological ecology of plants of the wet tropics. Dr W. Junk Publishers, Boston, Massachussetts, USA.

Dirzo, R. \& C.A. Domínguez. 1995. Plant-herbivore interactions in Mesoamerican tropical dry forests, p. 304-325. In S.H. Bullock \& H.A. Mooney (eds.). Seasonally dry tropical forests. Cambridge University, Cambridge, England.

Edwards, P.J. 1977. Studies of mineral cycling in a montane rain forest in New Guinea. Part 2. The production and disappearance of litter. J. Ecol. 65: 971-972.

Filip, V., R. Dirzo, J.M. Maass \& J. Sarukhán. 1995. Within and between year variation in the levels of herbivory on the foliage of trees from Mexican deciduous forest. Biotropica 27: 78-86.

Frankie, G.W. 1975. Tropical forest phenology and pollinator plant coevolution, p. 192-209. In L.E. Gilbert \& P.H. Raven (eds.). Coevolution of animals and plants. University of Texas, Austin, Texas, USA.

Frankie, G.W., H.G. Baker \& P.A. Opler. 1974. Comparative phenological studies of trees in tropical wet and dry forest in the lowlands of Costa Rica. J. Ecol. 62: 881-919.

Frith, C.B. \& D.W. Frith. 1985. Seasonality of insect abundance in an Australian upland tropical rain forest. Aust. J. Ecol. 10: 237-248.

Fuchs, E.J. 2000. Efecto del aislamiento espacial y fenológico sobre el flujo génico y el éxito reproductivo de Pachira quinata (Bombacaceae). Tesis de maestría, Universidad de Costa Rica, San José. 54 p.

Gentry, A.H. 1995. Diversity and floristic composition of neotropical dry forest, p. 146-194. In S.H. Bullok \& H.A. Mooney (eds.). Seasonally dry tropical forest. Cambridge University, Cambridge, England.

Gentry, A.H. 1974. Flowering phenology and diversity in tropical Bignoniaceae. Biotropica 6: 64-68.

Gillespie, T.W. 1999. Life history characteristics and rarity of woody plants in tropical dry forest fragments of Central America. J. Trop. Ecol. 15: 637-649.

Greig, N. 1993. Predispersal seed predation on five Piper species in tropical rainforest. Oecologia 93: 412-420.

Hartshorn, G.S. 1983. Plants, p. 118-127. In D.H. Janzen (ed.). Costa Rican Natural History. University of Chicago, Chicago, Illinois, USA.

Herrera, C.M. 1989. Vertebrate frugivorous and their interaction with invertebrate fruit predators: Supporting evidence from a Costa Rican dry forest. Oikos 54: 185-188. 
House, S.M. 1992. Population density and fruit set in three dioecious tree species in Australian tropical rain forest. J. Ecol. 80: 57-69.

Jackson, P.C., J. Cavalier, G. Goldstein, F.C. Meinzer \& N.M. Holbrook. 1995. Partitioning of water resources among plants of lowland tropical forest. Oecologia 101: 197-203.

Janzen, D.H. 1967. Synchronization of sexual reproduction of trees within the dry season in Central America. Evolution 21: 620-637.

Janzen, D.H. 1970a. Herbivores and the number of tree species in tropical forest. Amer. Nat. 501-28.

Janzen, D.H. 1970b. Jacquinia pungens, a heliophile from understory of deciduous forest. Biotropica 2: 112-119.

Janzen, D.H. 1971. Seed predation by animals. Ann. Rev. Ecol. Syst. 2: 465-92.

Janzen, D.H. 1977a. Intensity of predation on Pithecellobium saman (Leguminosae) seeds by Merobruchus columbinus and Stator limbatus (Bruchidae) in Costa Rican deciduous forest. Trop. Ecol. 18: 162-176.

Janzen, D.H. 1977b. Why fruits rot, seeds mold, and meet spoils. Amer. Nat. 11: 691-713.

Janzen, D.H. 1980. Specificity of seed-attacking beetles in Costa Rican deciduous forest. J. Ecol. 68: 929-952.

Janzen, D.H. 1981. Patterns of herbivory in a tropical deciduous forest. Biotropica 13: 271-282.

Janzen, D.H. 1983. Jacquinia pungens, p. 265-267. In D.H. Janzen (ed.). Costa Rican Natural History. The University of Chicago, Chicago, Illinois, USA.

Janzen, D.H. 1987. Insect diversity of a Costa Rican dry forest: why keep it, and how? Biol. J. Linn. Soc. 30: 343-356.

Jonhson, SD \& K.E. Steiner. 2000. Generalization versus specialization in plant pollination systems. Tree 15 : 140-143.

Justiniano, M.J. \& T.S. Fredericksen. 2000. Phenology of tree species in Bolivian dry forests. Biotropica 32: 276-281

Knudsen, J.T. \& B. Ståhl. 1994. Floral odours in the Theophrastaceae. Nord. J. Bot. 22: 259-268.

Leopold, A.C. \& P.E. Kriedemann. 1975. Plant growth and development. Mc Graw-Hill, New York, New York, USA. 524 p.

Lieberman, D. \& M. Lieberman. 1984. The causes and consequences of synchronous flushing in a dry tropical forest. Biotropica 16: 193-201.
Lowman, M.D. 1984. An assessment of techniques for measuring herbivory: Is rainforest defoliation more intense than we thought? Biotropica 16: 264-268.

Maron, J.L. 1998. Insect herbivory above and belowground: individual and joint effects on plant fitness. Ecology 79: 1281-1293.

Marquis, R.J. 1984. Leaf herbivores decrease fitness of a tropical plant. Science 226: 537-539.

Marquis, R.J. 1988. Phenological variation in the understory shrub Piper arieianum: causes and consequences. Ecology 69: 1552-1565.

Marquis, R.J. \& H.B. Braker. 1994. Plant-herbivore interactions: diversity, specifity and impact, p. 261-281. In L.A. Mcdade, K.S. Bawa, H.A. Hespenheide \& G.S. Hartshorn (eds.). La Selva: Ecology and natural history of a Neotropical Rain Forest. University of Chicago, Chicago, Illinois, USA.

Maschinski, J. \& T.G. Whitham. 1989. The continuum of plant responses to herbivory: The influence of plant association, nutrient availability, and timing. Am. Nat. 134:1-19.

Mopper, S. \& D. Simberloff. 1995. Differential herbivory in an oak population: the role of plant phenology and insect performance. Ecology 76: 1233-1241.

Morrison, K.D. \& E.G. Reekie. 1995. Pattern of defoliation and its effect on photosynthetic capacity in Oenothera biennis. J. Ecol. 83: 759-767.

Morrow, P.A. 1984. Assessing the effects of herbivory, p. 225-231. In E. Medina, H.A. Money \& C. VázquezYánes (eds.). Physiological ecology of plants of wet tropics. Dr W. Junk, Boston, Massachussetts, USA.

Murcia, C. 2002. Ecología de la polinización, p. 493-530. In M.R. Guariguata \& G.H. Kattan (eds.). Ecología y conservación de bosques Neotropicales. LUR, Costa Rica.

Murphy, P.G. \& A.E. Lugo. 1995. Dry forests of Central America and the Caribbean, p. 9-34. In S.H. Bullok \& H.A. Mooney (eds.). Seasonally dry tropical forests. Cambridge University, Cambridge, England.

Newstrom, L.E., G.W. Frankie, H. Baker \& R.K. Colwell. 1994. Diversity of long term flowering patterns, p. 143-160. In L.A. MacDade, K.S. Bawa, H.A. Hespenheide \& G.S. Hartshorn (eds.). La Selva: Ecology and natural history of a Neotropical Rain Forest. University of Chicago, Chicago, Illinois, USA.

Oberbauer, S. 1985. Plant water relations of selected species in wet and dry tropical lowland forest in Costa Rica. Rev. Biol. Trop. 33: 137-142. 
Rathcke, B. \& E.P. Lacey. 1985. Phenological patterns of terrestrial plants. Ann. Rev. Ecol. Syst. 16: 179-214.

Restrepo, C. 2002. Frugivoría, p. 531-557. In M.R. Guariguata \& G.H. Kattan (eds.). Ecología y conservación de bosques neotropicales. LUR, San José, Costa Rica.

Richards, A.J. 1997. Plant breeding systems. Chapman \& Hall, New York, New York, USA. 529 p.

Rivera, G., S. Elliot, L.S. Caldas, G. Nicolossi, V.T.R. Coradin \& R. Borchert. 2002. Increasing day-length induces spring flushing of tropical dry forest trees in the absence of rain. Trees 16: 445-456.

Roupsard, O., A. Ferhi, A. Granier, F. Pallo, D. Depommier, B. Mallet, H.I. Joly \& E. Dreyer. 1999. Reverse phenology and dry season water uptake by Faidherbia albida in an agroforestry parkland of Sudanese West Africa. Funct. Ecol. 13: $460-472$.

Sallabanks, R. \& S.P. Courtney. 1992. Frugivory, seed predation and insect-vertebrate interactions. Ann. Rev. Entomol. 37: 377-400.

Smythe, N. 1990. Abundancia estacional de insectos nocturnos en un bosque neotropical, p. 393-402. In E.G. Leigh Jr., A.S. Rand \& D.M. Windsor (eds.). Ecología de un bosque tropical: Ciclos estacionales y cambios a largo plazo. Instituto Smithsonian de Investigaciones Tropicales, Panama, Panama.

Ståhl, B. 1989. A synopsis of Central American Theophrastaceae. Nord. J. Bot. 9: 15-30.

Ståhl, B. 1995. A synopsis of Jacquinia (Theophrastaceae) in the Antilles and South America. Nord. J. Bot. 15: 493-511.

Stephenson, A.C. 1981. Flower and fruit abortion: proximate causes and ultimate functions. Ann. Rev. Ecol. Syst. 12: 253-279.

Stiles, E.W. 1980. Patterns of fruit presentation and seed dispersal in bird disseminated woody plants in the eastern deciduous forest. Amer. Nat. 116: 670-686.
Strauss, S.Y. \& W.S. Armbruster. 1997. Linking herbivory and pollination-new perspectives on plant and animal ecology and evolution. Ecology 78:1617-1618.

SYSTAT. 1999. SYSTAT version 9.0 for Windows. SPSS, Chicago, Illinois, USA.

Tosi Jr., J.A. 1969. Mapa ecológico, República de Costa Rica: según la clasificación de zonas de vida del mundo de L.R. Holdridge. Centro Científico Tropical, San José.

Van Shaik, C.P., J.W. Terborgh \& S.J. Wright. 1993. The Phenology of tropical forest: adaptative significance and consequences for primary consumers. Annu. Rev. Ecol. Syst. 24: 353-77.

Wheelwright, N.T. 2000. A hypothesis about the timing of flowering fruiting in competing tropical trees, $\mathrm{p}$. 281-283. In N.M. Nadkarni \& N.T. Wheelwright (eds.). Monteverde: Ecology and conservation of a tropical cloud forest. Oxford University, Oxford, England. 561 p.

Wickens, G.E. 1969. A study of Acacia albida Del. (Mimosoideae). Kew Bulletin 23: 181-202.

Wisdom, C.S., C.S. Crawford \& E.F. Aldon. 1989. Influence of insect herbivory on photosynthetic area and reproduction in Gutierrezia species. J. Ecol. 77: 685-692.

Wolda, H. 1988. Insect seasonality: why? Ann. Rev. Ecol. Syst. 19: 1-18.

Wolda, H. 1990. Estacionalidad de los Homoptera de la isla de Barro Colorado, p. 403-414. In E.G. Leigh Jr., A.S. Rand \& D.M. Windsor (eds.). Ecología de un bosque tropical: Ciclos estacionales y cambios a largo plazo. Instituto Smithsonian de Investigaciones Tropicales, Panama, Panama.

Wright, S.J. \& F.H. Cornejo. 1990. Seasonal drought and the leaf fall in tropical forest. Ecology 71: 1165-175.

Wright, S.J. 1996. Phenological responses to seasonality in tropical forest plants, p. 440-460. In S.S. Mulkey, R.L. Chazdon \& A.P. Smith (eds.). Tropical forest plant ecophysiology. Chapman \& Hall, New York, New York, USA. 
